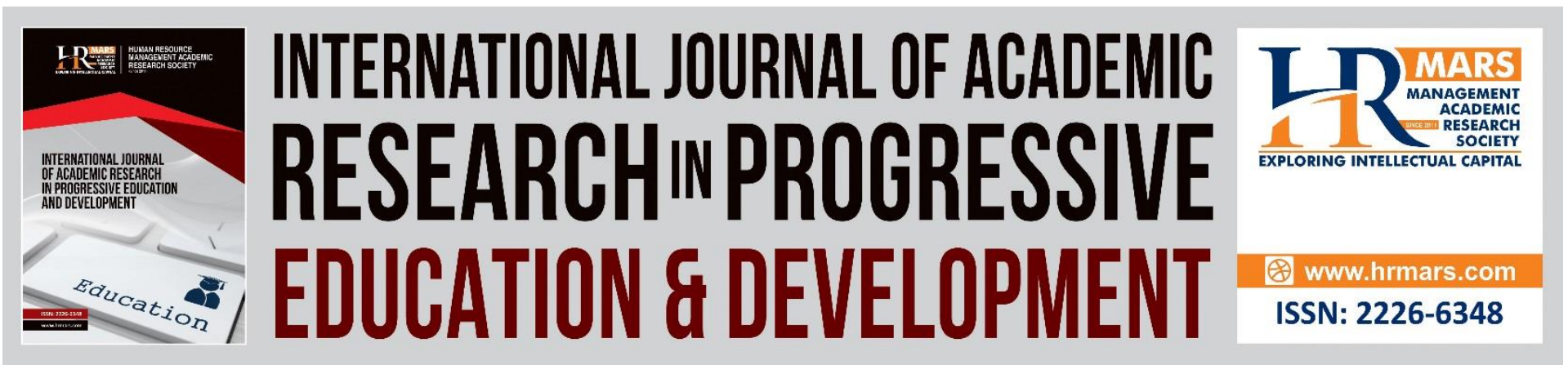

\title{
Word Webbing as an Effective Technique to Teach Descriptive Writing
}

Susi Nur Wahyuni, Wahyu Taufiq, Dian Rahma Santoso, Kamarul Shukri Mat Teh, Mohamad Zaidin Mohamad

To Link this Article: http://dx.doi.org/10.6007/IJARPED/v8-i2/5814

DOI: $10.6007 /$ IJARPED/v8-i2/5814

Received: 10 Jan 2019, Revised: 21 Feb 2019, Accepted: 10 March 2019

Published Online: 13 March 2019

In-Text Citation: (Wahyuni, Taufiq, Santoso, Teh, \& Mohamad, 2019)

To Cite this Article: Wahyuni, S. N., Taufiq, W., Santoso, D. R., Teh, K. S. M., \& Mohamad, M. Z. (2019). Word Webbing as an Effective Technique to Teach Descriptive Writing. International Journal of Academic Research in Progressive Education and Development, 8(2), 286-297.

Copyright: (C) 2019 The Author(s)

Published by Human Resource Management Academic Research Society (www.hrmars.com)

This article is published under the Creative Commons Attribution (CC BY 4.0) license. Anyone may reproduce, distribute, translate and create derivative works of this article (for both commercial and non-commercial purposes), subject to full attribution to the original publication and authors. The full terms of this license may be seen

at: http://creativecommons.org/licences/by/4.0/legalcode

Vol. 8(2) 2019, Pg. 286 - 297

http://hrmars.com/index.php/pages/detail/IJARPED

JOURNAL HOMEPAGE

Full Terms \& Conditions of access and use can be found at http://hrmars.com/index.php/pages/detail/publication-ethics 


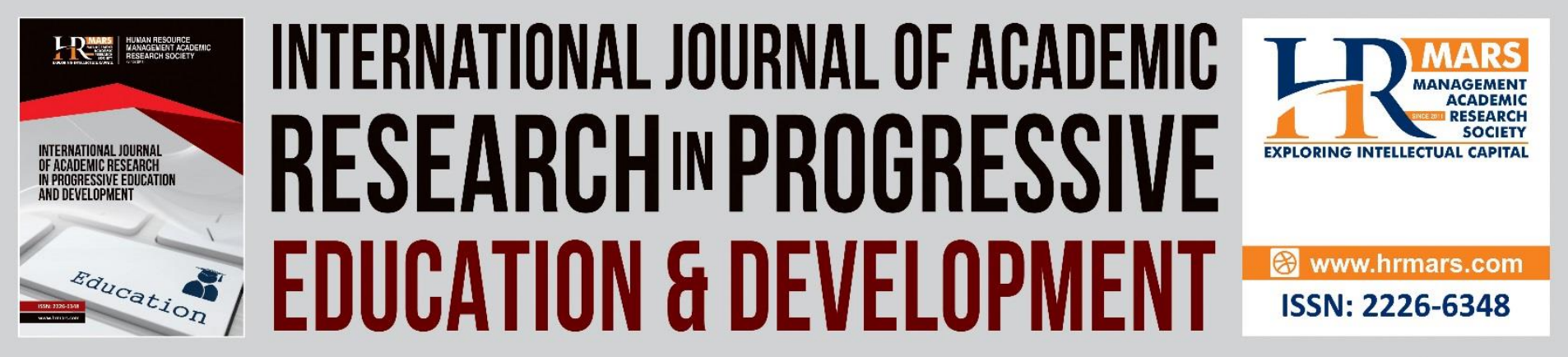

\title{
Word Webbing as an Effective Technique to Teach Descriptive Writing
}

\author{
Susi Nur Wahyuni ${ }^{1}$, Wahyu Taufiq ${ }^{1}$, Dian Rahma Santoso ${ }^{1}$, \\ Kamarul Shukri Mat Teh², Mohamad Zaidin Mohamad² \\ ${ }^{1}$ Fakultas Keguruan dan IImu Pendidikan, Universitas Muhammadiyah Sidoarjo, Indonesia \\ ${ }^{2}$ Fakulti Pengajian Kontemporari Islam, Universiti Sultan Zainal Abidin, Malaysia \\ Corresponding Author Email:kamarul@unisza.edu.my
}

\begin{abstract}
One language which is popular nowadays is English. English is an international language that is very popular for global communication. English itself is an international language, which is used as a medium of interaction and communication among people from different parts of the world. The purpose of this research is to propose an alternative technique to help students learn descriptive text better. This research aims at investigating a writing teaching technique using word webbing since the teaching and learning process, particularly in descriptive text, is challenging. The effectiveness of using word webbing in enhancing students' ability to compose descriptive text is measured by using the quantitative method. Using an experimental and control group, the researchers used the quasi experimental method to collect the data and counted it using the t-test formula. According to the statistical calculation, it is found that the word webbing technique is significantly effective in supporting the students' ability to learn descriptive text.
\end{abstract}

Keywords: Word Webbing, Teaching, Writing

\section{Introduction}

Language is the basic tool for communication. In this era, people are urged to at least understand more than one language in order to follow global communications and information. One language which is popular nowadays is English. English is an international language that is very popular for global communication. English itself is an international language, which is used as a medium of interaction and communication among people from different parts of the world (Taufiq, 2016).

There are four skills in teaching English. They are writing, speaking, reading and listening. Writing is one of the English skills which is mainly discussed in this research. It is one of English skills that urges the learners to develop their creativity since they need to produce the language work. As suggested by White (1986), writing is an activity that enables one to share ideas, increase feelings, persuade, and convince other people to believe. By writing, students can develop their language to express their knowledge, experiences, and ideas. 
INTERNATIONAL JOURNAL OF ACADEMIC RESEARCH IN PROGRESSIVE EDUCATION AND DEVELOPMENT

Vol. 8, No. 2, 2019, E-ISSN: 2226-6348 @ 2019 HRMARS

According to Megawati (2012), writing is one of the crucial ways to deliver information through a language which must be mastered by both the writer and the reader. Nunan (1991) states that writing is an extremely complex cognitive activity that requires the writer to demonstrate control of several variables at once. Also, Harmer (1991) in his book mentions that writing with mistakes and half-finished sentences would be judged by many illiterate native speakers since it is expected that writing should be perfect. Learning to write in a foreign or a second language mainly involves linguistic knowledge and the vocabulary choices sytactic patterns, and cohesive devices that comprise the essential building blocks of the texts (Hyland, 2003).

In Junior High School, students need to write different text types. There are some text types that must be learned; those are Recount, Narrative, Procedure, and Descriptive. Based on primary investigation in some schools in certain areas in Indonesia, the researchers found the students encountered difficulties in writing descriptive text. Therefore, they focused on this kind of text.

Teaching is any action performed by a teacher with the intention to facilitate the learning process of the learner (Syah, 1995). The teacher can use some methods or techniques to teach writing materials. Here, the researchers suggested the use of a particular model to help students to study the writing skill so called the word webbing.

Word webbing is a model of teaching on how to creatively think with a chart and improve the draft development and idea. Ideally, the student can learn the descriptive text from time to time to develop their ideas and critical thinking. Starko (2010) says that word webbing is often used to organize such ideas and information on a topic. Additionally, the word webbing technique should be used when students are just beginning to learn to construct meaning and can use it to formulate their own purposes or pre-questions or when the text is extremely difficult (Cooper, 2001). Haris (2011) states that the concept of word webbing is that students write simultaneosly on a piece of chart paper, drawing main concepts, supporting elements, and bridges representing the relation of ideas in a concept. It also gives the students ideas about what to write in the next paragraph based on the keywords that they have written on the paper. Mc Donald \& Hershman (2010) state that with the word webbing technique, the students draw a circle in the middle of a paper and write the title of the book in it. The word webbing technique is better than others because the students must arrange the main ideas first. Richards (1998) says in his article that children often overlook important details and omit adjectives as they struggle to put their thoughts on paper. By using word webbing, students can be assisted to avoid this.

Practically, as proposed by McDonald \& Hershman (2010: 239), in the word webbing strategy, the students can draw a circle in the middle of their paper and write the title of the book in it. Then they draw other circles off the main one for each paragraph and write the main idea for one paragraph in each of the smaller circles (refer Figure 1). The word webbing technique can also be used to break down a textbook chapter by putting the paragraph title in the middle and then having the main ideas sprout off the circle in the middle. 


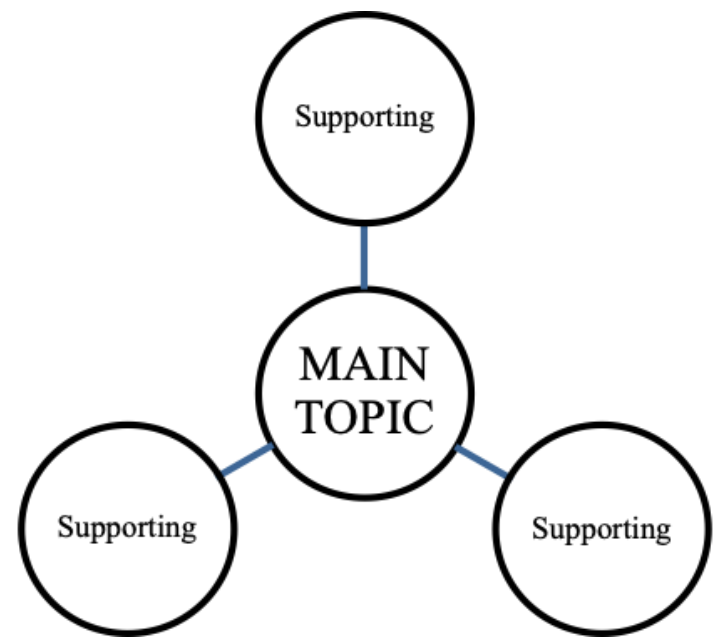

Figure 1 Word Webbing Strategy

Previously, there were studies which were conducted by Agustini and Sianipar (2015) who analyzed word webbing as a technique to teach speaking. Musdalifah (2008) also used word webbing to compose descriptive text. Word webbing does not only help the students to organize and generate their ideas, but also help their brains to focus on the structure and arrangement of the ideas into cohesive and coherent paragraphs. Word webbing is a technique of arranging and exploring ideas. By using word webbing in descriptive writing, the students are eased in making arrangements from their ideas.

Based on the reasons above, the researchers conducted a study on the effectiveness of using word webbing to increase the students' ability to compose descriptive text. This research focused on whether the use of the word webbing technique is effective in increasing the students' writing skill in descriptive text and how successful it is in increasing the students' writing ability. Objectively, it is aimed to know whether word webbing is an effective tool in increasing the students' writing skill in descriptive text and to find out how successful is the use of the word webbing technique in increasing the students' writing skill in descriptive text.

\section{Methodology}

In this research, the effectiveness of using the word webbing technique to enhance students' ability to compose descriptive text is measured using the quantitative method. Ary (2010) says that quantitative research is investigation which uses definition to generate numeric data to answer hypotheses or questions. It means that quantitative research is the act of collecting data with numerics in statistics. In order to attain this quantitative data, the researchers specifically used the quasi-experimental method in collecting the data.

The method of the study is quantitative with a pre-test and post-test and the design is quasiexperimental. Quasi-experimental research is a method that does not use random picking because the setting makes it unable to be used in determining the sample and it is commonly useful in knowing the potency and impact of an educational plan. In that location, two variables were involved in this inquiry. They were the word webbing technique as an independent variable and descriptive writing as a dependent variable. 
The results of two classes were compared and observed, in order to know if there are any significant differences in teaching descriptive writing with and without using the word webbing technique. They were an experimental class and a controlled class. Furthermore, the word webbing technique was employed in teaching descriptive writing in the experimental class and it was not applied in the controlled class.

The test was used as the instrument for this study. The exam was applied twice, before and after the intervention or teaching and learning process using the word webbing technique. The pre-test was employed with the intention to know the writing skills of the sample and the post-test was employed with the intention to check whether the task had an effect or not on the students' writing skills. The pre-test was administered before giving the intervention, while the post-test was given after the intervention. In the test, students were asked to write a paragraph from one of the topics in the descriptive text, which was about animals. Students were given several minutes to find the ideas in making descriptive writing.

And so, in the post-test students were needed to write the same topic. The instruments for both tests were attached. The validity of the instrument had been tested by using the content validity index. The instrument can be said to have content validity when it can clearly define what it wants to measure.

\section{Results and Discussion}

The technique used for collecting the data in this study is the pre and post-test whereby the students' test results were studied. The researchers gave a pre-test to the students from the experiment class. The purpose of giving the pre-test is to know the basic knowledge of the students before the intervention. The researcher used the intervention during two meetings in teaching word webbing to compose descriptive text for the experimental class and without the word webbing technique for the control class. In the first meeting, the researchers explained about the kinds of descriptive text and ask the students to make a descriptive text in the experimental class. In the second meeting, the researcher taught using the word webbing technique.

The researchers also gave a pre-test to both the students in the experiment and control class. The purpose of giving the post-test is to know students' understanding after the intervention was given. Analysis of the data was done after the students had finished doing their pretest and posttest. In this study, analytical scoring by Anderson in Huges (2003) was used in order to be able to give, analyze, and prove the reliability of the students' score. The scale of the scoring is as follows:

\section{T-test}

T-test is also called as the partial test. It is used to know whether there are any differences before and after intervention.

$$
t_{0}=\frac{\mathrm{M} 1-\mathrm{M} 2}{\mathrm{SEM} 1-\mathrm{M} 2}
$$

M1 : Mean of the Difference of Experiment Class

M2 : Mean of the Difference of Control Class

SEM : Standard Error of Experiment Class

SEM2 : Standard Error of Control Class

The Procedure of calculation were as follows: 
INTERNATIONAL JOURNAL OF ACADEMIC RESEARCH IN PROGRESSIVE EDUCATION AND DEVELOPMENT

Vol. 8, No. 2, 2019, E-ISSN: 2226-6348 C 2019 HRMARS

1. Determining Mean of variable $X$, the formula is:

$$
\overline{M_{1}}=\sqrt{\frac{\sum x}{N_{1}}}
$$

2. Determining Mean of variable $Y$, the formula is:

$$
\mathrm{M}_{2}=\frac{\overline{\sum \mathrm{Y}}}{\sqrt{\mathrm{N}_{2}}}
$$

3. Determining standard of deviation score of variable $\mathrm{X}$, the formula is:

$$
\overline{\mathrm{SD}_{1}}=\sqrt{\frac{\sum_{\mathrm{X}}^{2}}{\mathrm{~N}_{1}}}
$$

4. Determining standard of deviation score of variable $Y$, the formula is:

$$
\mathrm{SD}_{2}=\sqrt{\frac{\sum_{\mathrm{x}} 2}{\mathrm{~N}_{2}}}
$$

5. Determining standard error of mean of variable $X$, the formula is:

$$
\overline{\mathrm{SE}_{\mathrm{M}_{1}}}=\frac{\mathrm{SD}_{1}}{\sqrt{\mathrm{N}_{1}-1}}
$$

6. Determining standard error or mean of variable $\mathrm{Y}$, the formula is:

$$
\mathrm{SE}_{\mathrm{M}_{2}}=\frac{\mathrm{SD}_{2}}{\sqrt{\mathrm{N}_{2}-1}}
$$

7. Determining standard error of difference of mean of variable $X$ and variable $Y$, with formula:

$$
\overline{S E_{\mathrm{M}_{1-} M_{2}}}=\sqrt{\sqrt{S E_{M_{1}}{ }^{2}+S E_{M_{2}}{ }^{2}}}
$$

8. Determining $\mathrm{t}_{0}$ with formula:

$$
t_{0}=\frac{\mathrm{M} 1-\mathrm{M} 2}{\mathrm{SEM} 1-\mathrm{M} 2}
$$

9. Determining t-table in significance level $5 \%$ with degree of Freedom (df):

$\mathrm{df}=\left(\overline{N_{1}}+\overline{N_{2}}\right)-2$

Variable $X \quad$ : Teaching writing descriptive using word webbing

Variable $Y \quad$ : Teaching writing descriptive without using word webbing.

Table 1: Result of the Pretest and Posttest.

\begin{tabular}{llccc}
\hline No & \multicolumn{1}{c}{ Sample } & Pre Test Score & $\begin{array}{c}\text { Post Test } \\
\text { Score }\end{array}$ & Gained Score \\
\hline 1. & $\begin{array}{l}\text { Experimental } \\
\text { Class }\end{array}$ & 56.80 & 76.38 & 19.58 \\
2. $\quad$ Controlled Class & 60.71 & 74.14 & 13.42 \\
\hline
\end{tabular}

Table 1 shows the students' pre test scores in the experimental class and controlled class. The test was given in the last meeting after the intervention. The total gained scores from the experimental class is 19.58 and for the controlled class is 13.42 .

To answer the question on whether the word webbing technique is effective in increasing the students' ability, the researchers used the t-test and conducted it in both the experimental class and controlled class by using SPSS: 
INTERNATIONAL JOURNAL OF ACADEMIC RESEARCH IN PROGRESSIVE EDUCATION AND DEVELOPMENT

Vol. 8, No. 2, 2019, E-ISSN: 2226-6348 @ 2019 HRMARS

Table 2: One-Sample Kolmogorov-Smirnov Test (Pre Test)

\begin{tabular}{|c|c|c|c|}
\hline & & $\begin{array}{l}\text { Pretest } \\
\text { Control }\end{array}$ & Pretest Experiment \\
\hline \multicolumn{2}{|l|}{$\mathrm{N}$} & 35 & 36 \\
\hline \multirow[t]{2}{*}{ Normal Parameters ${ }^{\mathrm{a}}$} & Mean & 60.71 & 56.81 \\
\hline & $\begin{array}{l}\text { Std. } \\
\text { Deviation }\end{array}$ & 9.482 & 8.956 \\
\hline Most Extreme & Absolute & .160 & .191 \\
\hline \multirow[t]{2}{*}{ Differences } & Positive & .127 & .191 \\
\hline & Negative & -.160 & -.094 \\
\hline \multicolumn{2}{|l|}{ Kolmogorov-Smirnov Z } & .947 & 1.146 \\
\hline \multicolumn{2}{|l|}{ Asymp. Sig. (2-tailed) } & .331 & .145 \\
\hline
\end{tabular}

Table 3: One-Sample Kolmogorov-Smirnov Test (Post Test)

\begin{tabular}{|c|c|c|c|}
\hline & & Posttest Control & Posttest Experiment \\
\hline \multicolumn{2}{|l|}{$\mathrm{N}$} & 35 & 36 \\
\hline \multirow[t]{2}{*}{ Normal Parameters ${ }^{a}$} & Mean & 74.14 & 76.39 \\
\hline & Std. Deviation & 6.585 & 5.293 \\
\hline \multirow{3}{*}{$\begin{array}{l}\text { Most Extreme } \\
\text { Differences }\end{array}$} & Absolute & .180 & .215 \\
\hline & Positive & .163 & .215 \\
\hline & Negative & -.180 & -.202 \\
\hline \multicolumn{2}{|l|}{ Kolmogorov-Smirnov Z } & 1.067 & 1.288 \\
\hline \multicolumn{2}{|l|}{ Asymp. Sig. (2-tailed) } & \multicolumn{2}{|l|}{.205} \\
\hline & Gained Control & Gained Experiment \\
\hline \multicolumn{2}{|l|}{$\mathrm{N}$} & 35 & 36 \\
\hline \multirow[t]{2}{*}{ Normal Parameters ${ }^{a}$} & Mean & 13.43 & 19.58 \\
\hline & $\begin{array}{l}\text { Std. } \\
\text { Deviation }\end{array}$ & 10.345 & 8.894 \\
\hline \multirow[t]{3}{*}{ Most Extreme Differences } & S Absolute & .137 & .213 \\
\hline & Positive & .116 & .121 \\
\hline & Negative & -.137 & -.213 \\
\hline \multicolumn{2}{|l|}{ Kolmogorov-Smirnov Z } & .813 & 1.279 \\
\hline \multicolumn{2}{|l|}{ Asymp. Sig. (2-tailed) } & .524 & .076 \\
\hline
\end{tabular}


INTERNATIONAL JOURNAL OF ACADEMIC RESEARCH IN PROGRESSIVE EDUCATION AND DEVELOPMENT

Vol. 8, No. 2, 2019, E-ISSN: 2226-6348 C 2019 HRMARS

From the Table 2- 4 Sample Kolomogorov-smirnov test about the pre-test, the post-test and the gained score of both classes, it was found that the significance score in Asymp. Sig. (2tailed) is higher than 0.05 with $\alpha=5 \%$. Based on the Santoso (2006) opinion "jika nilai sig. atau signifikansi atau nilai probabilitas $>0.05$ maka distribusi adalah normal". So this means the distribution of the data is normal. The Procedure of calculation were as follows:

10. Determining Mean of variable $X$, the formula is:

$$
\overline{M_{1}}=\frac{\overline{\sum x}}{N_{1}}=\frac{705}{36}=19.58
$$

11. Determining Mean of variable $Y$, the formula is:

$$
\underline{\mathrm{M}_{2}}=\frac{\overline{\sum_{\mathrm{Y}}}}{\sqrt{\mathrm{N}_{2}}}=\frac{\overline{470}}{35}=13.42
$$

12. Determining standard of deviation score of variable $X$, the formula is:

$$
\overline{\mathrm{SD}_{1}}=\sqrt{\sqrt{\frac{\sum_{\mathrm{x}}^{2}}{\mathrm{~N}_{1}}}}=\sqrt{\frac{19.58^{2}}{36}}=\sqrt{\frac{383.3}{36}}=\sqrt{10.64}=\mathbf{3 . 2 6}
$$

13. Determining standard of deviation score of variable $\mathrm{Y}$, the formula is:

$$
\mathrm{SD}_{2}=\sqrt{\frac{\sum_{\mathrm{x} 2}}{\mathrm{~N}_{2}}}=\sqrt{\frac{13.42^{2}}{35}}=\sqrt{\frac{180.0 \mathrm{c}}{35}}=\sqrt{5.14}=\mathbf{2 . 2 6}
$$

14. Determining standard error of mean of variable $X$, the formula is:

$$
\begin{aligned}
\mathrm{SE}_{\mathrm{M}_{1}} & =\frac{\mathrm{SD}_{1}}{\sqrt{\mathrm{N}_{1}-1}}=\frac{3.26}{\sqrt{36-1}} \\
& =\frac{3.2 \epsilon}{\sqrt{35}}=\frac{3.2 \epsilon}{5.91}=\mathbf{0 . 5 5}
\end{aligned}
$$

15. Determining standard error or mean of variable $\mathrm{Y}$, the formula is:

$$
\begin{aligned}
\mathrm{SE}_{\mathrm{M}_{2}} & =\frac{\mathrm{SD}_{2}}{\sqrt{\mathrm{N}_{2}-1}}=\frac{2.26}{\sqrt{35-1}} \\
& =\frac{2.2 \epsilon}{\sqrt{34}}=\frac{2.2 \epsilon}{5.83}=\mathbf{0 . 3 8}
\end{aligned}
$$

16. Determining standard error of difference of mean of variable $X$ and variable $Y$, with formula:

$$
\begin{array}{rlr}
\mathrm{SE}_{\mathrm{M}_{1-M_{2}}} & =\sqrt{\mathrm{SE}_{\mathrm{M}_{1}{ }^{2}+\mathrm{SE}_{\mathrm{M}_{2}}{ }^{2}}} \\
& =\sqrt{0.55^{2}+0.38^{2}} \\
& =\sqrt{\frac{\sqrt{0.30+0.14}}{}}=\mathbf{0 . 6 6 3} \\
& =\sqrt{0.49}
\end{array}
$$

17. Determining $\sqrt{t_{0}}$ with formula:

$$
\begin{array}{rl|l}
t_{0} & =\frac{\mathrm{M} 1-\mathrm{M} 2}{\frac{\mathrm{SEM} 1-\mathrm{M} 2}{19.58-13.42}} \\
& =\frac{0.663}{0.663} \\
& =\frac{6.16}{0.663}=9.29
\end{array}
$$

18. Determining t-table in significance level $5 \%$ with degree of Freedom (df):

$$
\begin{aligned}
\mathrm{df} & =\left(\overline{N_{1}}+\left(\overline{N_{2}}\right)-2\right. \\
& =(36+35)-2
\end{aligned}
$$


INTERNATIONAL JOURNAL OF ACADEMIC RESEARCH IN PROGRESSIVE EDUCATION AND DEVELOPMENT

Vol. 8, No. 2, 2019, E-ISSN: 2226-6348 @ 2019 HRMARS

$=69$

Therefore, the degree of freedom (df) is 69 and the critical value of the $\mathrm{df} 69$ by using the degree of significance $5 \%$ is 1.994 and the $t_{\text {observe }}$ is 9.29 .

Distinctly, it can be seen that the post test score of the experimental class is higher than the score of the controlled class. The result of the comparison of $t_{\text {observe }}$ and $t_{\text {table }}$ is $9.29>1.99=t_{\text {observe }}>t_{\text {table }}$.

The Alternative Hypothesis $(\mathrm{Ha})$ and the Null Hypothesis $(\mathrm{Ho})$ are as follows:

1. The Null Hypothesis (Ho): There is no significant difference between students' who wrote descriptive text using the word webbing technique with students that were taught without the word webbing technique.

2. The Alternative Hypothesis ( $\mathrm{Ha}$ ): There is significant difference between students' who wrote descriptive text using the word webbing technique with students that were taught without the word webbing technique.

After calculating the data, the researcher test the hypothesis based on the statistical hypothesis. Here are the hypothesis:

1. If t-test $\left(\underline{t_{0}}\right)>\mathrm{t}$-table $\left(\underline{t_{t}}\right)$ : There is significant difference between students' who wrote descriptive text using the word webbing technique with students that were taught without the word webbing technique.

2. If t-test $\left(t_{0}\right)<\mathrm{t}$-table $\left(t_{t}\right)$ : There is no significant difference between students' who wrote descriptive text using the word webbing technique with students that were taught without the word webbing technique.

Based on the analysis of the results above, there is a significant difference between the scores of the posttest from the experimental class and the controlled class. The mean score of the pretest is $\mathbf{5 6 . 8 0}$ from the experimental class while the mean score is 60.71 for the controlled class. The mean score of the post test is 79,58 from the experimental class while the score is 76,38 for the controlled class. The gained scores of the experimental class is 19.58 and for the controlled class is 13,42 .

To know whether there is significant effect of using word webbing in descriptive text or not, the researcher used the eta-square formula to calculate it.

$$
\begin{aligned}
\text { Eta-Square } & =\frac{\mathrm{t}^{2}}{\mathrm{t}^{2}+\mathrm{N}-2} \\
& =\frac{\frac{9.29^{2}}{9.29^{2}+71-2}}{86.3} \\
& =\frac{86.3+69}{86.3} \\
& =0.55
\end{aligned}
$$

The value of the eta-square formula can range from 0 to 1 . This means that the smallest value is 0.01 and the largest value is 1 . To interpret the strength of the eta-square value, it can be known from the criteria bellow:

Table 5: Eta-square Values Criteria

\begin{tabular}{cc}
\hline Value & Effect \\
\hline $0.01-0.05$ & Small \\
$0.06-0.13$ & Moderate / Medium \\
$0.14-1$ & Large / Significant \\
\hline
\end{tabular}


Based on the data calculated above, the eta-squared value is 0.55 , which means word webbing does have significant effect. In other words, the alternative hypothesis $\left(\overline{\mathrm{H}_{\mathrm{a}}}\right)$ of this research is accepted and the null hypothesis $\left(\overline{\mathrm{H}_{0}}\right)$ is rejected. So it can be concluded that there is significant effect on students' understanding when they are taught descriptive text using word webbing.

Below is the diagram of the mean scores of the experimental class and controlled class in the pretest and posttest.

Figure 2: Mean of Pre Test and Post Test

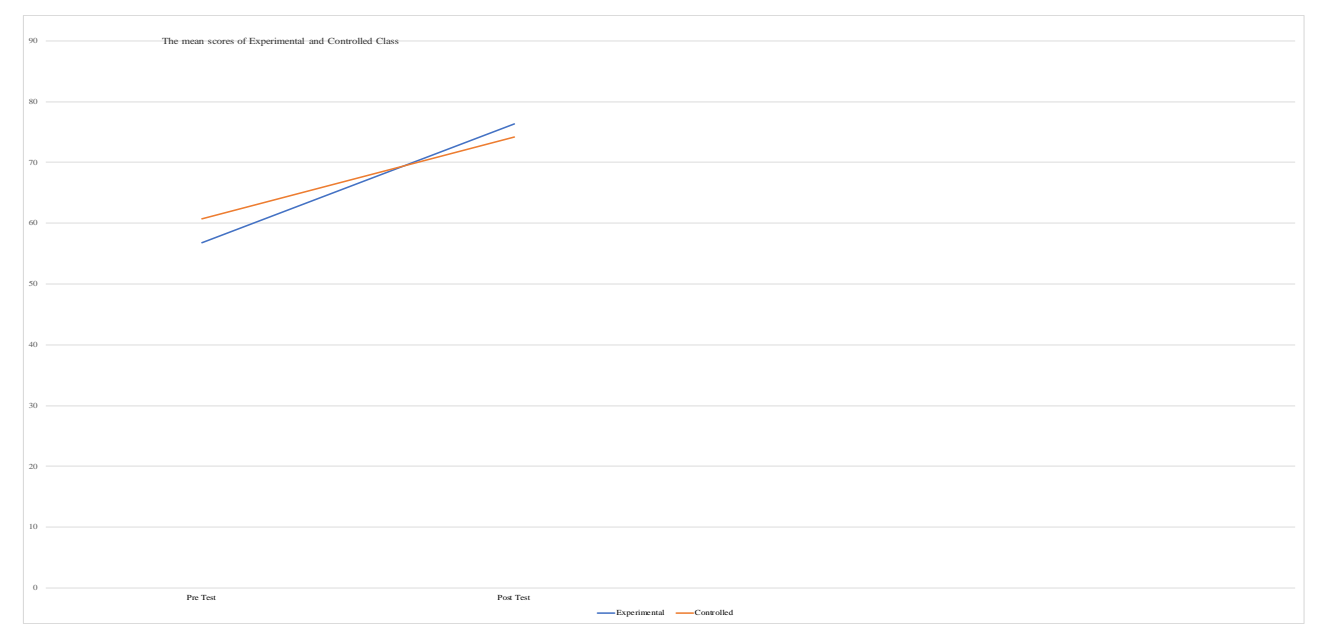

It can be concluded that from the description above, the mean score of the post-test from the experiment class which were given the intervention had a higher score than the score from the controlled class which were not given any intervention. So this means that there is a significant effect on students' understanding when they use word webbing in writing of descriptive text.

The results of the report of the T-test is higher than t-table $(9.29>1.99)$. It can be shown that teaching writing of descriptive text by using word webbing is more effective than teaching writing of descriptive text without using word webbing since the alternative hypothesis $(\mathrm{Ha})$ is accepted and the null hypothesis is rejected. In other words, teaching writing of descriptive text by using word webbing gives positive influence on the students' achievement.

It can be concluded that from the description above, the scores of the post-test from the experiment class which were given the intervention had higher scores than from the controlled class which were not given any intervention. So this means that there was significant effect on students' understanding when using the word webbing as a technique to teach writing.

It can be shown that teaching writing by using the word webbing technique is more effective than teaching writing without using the word webbing technique as teaching writing by using the word webbing technique gave positive influence on the students' achievements.

\section{Conclusion}

This research was conducted by using the quasi-experimental design which is directed to find out whether the word webbing technique is effective in teaching writing. Based on the statistical 
INTERNATIONAL JOURNAL OF ACADEMIC RESEARCH IN PROGRESSIVE EDUCATION AND

DEVELOPMENT

Vol. 8, No. 2, 2019, E-ISSN: 2226-6348 @ 2019 HRMARS

calculation, there is a significant difference between teaching writing using the word webbing technique and without using the word webbing technique. Hence, the word webbing technique is effective in teaching writing which in turn enhances students' achievement.

\section{Acknowledgement}

The researchers would like to say thank you to all of the students, especially the students who helped the researcher in conducting this study.

\section{References}

Agustini, I., \& Sianipar, Y. A. (2015). Improving Students' Vocabulary Achievement through Word Webbing Technique. Journal of English Language Teaching and Learning of FBS UNIMED, 4(1), 1-13.

Ary, D. J. \& Razavie. (2010). Introduction to Research in Education (eight edition), United Stated: Waddsworth Cangange Learing. New york: CBS college publishing.

Cooper, D.J. (2001). Literacy Helping Children Contruct Meaning. Boston: Houghton Mifflin Company.

Haris, M. M. (2011). The Effectiveness of Using Word Webbing to Increase the Students' Speaking Skill Ability in News Item. Thesis MA. English Department and Education Faculty, IAIN Walisongo, Semarang.

Harmer, J. (1991). The Practice of English Language Teaching. New York: Longman Publishing.

Hughes, A. (2003). Testing for Language Teachers. Second Edition. Cambridge : Cambridge University Press.

Hyland, K. (2003). Second Language Writing. UK: Cambridge University Press.

Mc Donald \& Hershman. (2010). Classroom That Spakr! San Fransisco: Jossey-Bass.

Megawati, F. (2012). Comic Strips: A study on the Teaching of Writing Narrative Texts to Indonesian EFL Students.Teflin Journal. 23(2): 183-205.

Muzdalifah, V. (2008). The use of mind mapping to improve the descriptive text writing abilities of the 10th grade students. Unpublished Thesis, English Department, UNESA, Surabaya.

Hassan, A. B \& Khairuldin, W.M.K.F.W. (2019). Smart Quran Application: Authority of Digital Mushaf Usage in Malaysia. International Journal of Civil Engineering and Technology, 10(3). pp. 3315-3322.

Khairuldin, W. M. K. F. W., Anas, W. N. I. W. N., \& Embong, A. H. (2018). Experts' View within Fatwa Production in Malaysia. International Journal of Academic Research in Business and Social Sciences, 8(11), 530-538.

Khairuldin, W.M.K.F.W., Embong, A.H., Anas, W.N.I.W.N., Mohd, H. \& Ismail, D. (2018), The Application of Technology in the Dissemination of Fatwas: A Study on Religious Institutions in Malaysia, International Journal of Civil Engineering and Technology, 9(7), 2018, pp. 15901596

Nunan, D. (2015). Teaching English to Speakers of Other Languages. New York: Routledge.

Richards, K. (1993). Using Semantic Mapping, Cooperative Groups, and Toys to Build Descriptive Writing. The Reading Teacher, 46(5), 449-451.

Santoso. (2006). Menggunakan SPSS untuk Statistik Parametrik. Pt elex media komputindo, Jakarta. 
Starko, A. J. (2010). Creativity in The Classroom: School of Curious Delight. New York: Routledge. Sugiyono, (2008). Metode Penelitian Kuantitatif Kualitatif dan R\&D. Bandung: Alfa Beta.

Syah, M. (1995). Psikologi Pendidikan. Bandung: Remaja Rosdakarya.

Taufiq, W. (2016). A Case Study of an ESL Student Learning English in an English Speaking Country. Jurnal Pedagogia. 5(2): 287-296.

White, F.D. (1986). The Writers Art. A practical rhetoric \& handbook. California: Wadsworth Publishing Company. 